\title{
Scoping the Possibilities: Student Preferences towards Open Textbooks Adoption for E-Learning
}

\author{
Deepak Prasad, Tsuyoshi Usagawa \\ Department of Computer Science and Electrical Engineering, Graduate School of Science and Technology, \\ Kumamoto University, Kumamoto, Japan \\ Email: deepak.v.prasad@gmail.com, tuie@cs.kumamoto-u.ac.jp
}

Received 11 October 2014; revised 6 November 2014; accepted 22 November 2014

Copyright @ 2014 by authors and Scientific Research Publishing Inc.

This work is licensed under the Creative Commons Attribution International License (CC BY). http://creativecommons.org/licenses/by/4.0/

(c) (i) Open Access

\begin{abstract}
Many universities have begun implementing e-Learning systems due to their low cost. However, publishers of expensive textbooks stand in the way of e-Learning's ability to provide a cost-effective educational delivery model. While many universities aim to overcome this opposition and replace traditional publishers' textbooks with free open textbooks, such plans cannot be executed successfully unless students are open to their use. As such, a study into students' preferences towards open textbook adoption is vital to provide clear indication as to their opinions regarding open textbook use. Thus, this study conducted a study of University of the South Pacific (USP) students' preferences towards open textbook adoption for e-Learning using a survey administered during Semester 2, 2013 which generated 1077 responses. Areas examined include: Impacts of textbook costs on students' academic careers; preferences towards open textbook adoption; perceived barriers to and motivations for adoption of open textbooks; and preferred digital features and reading devices. Results show that textbook prices adversely impact students. Furthermore, a high level of acceptance towards the adoption of open textbooks was found. The study revealed that the preference for reading printed material was the highest rated barrier to open textbook adoption, while the free availability of open textbooks was rated the greatest motivator. Study findings are being used to inform efforts to develop open textbooks at the USP and may assist other universities seeking to start similar projects.
\end{abstract}

\section{Keywords}

Open Textbook, Digital Textbook, Student Preferences, Adoption, E-Learning, The University of the South Pacific 


\section{Introduction}

E-learning is being adopted by many universities throughout the world as a cost-effective educational delivery model for expanding and widening access to higher education for all. The University of the South Pacific (USP), a dual-mode regional university co-owned by 12 Pacific island countries (Cook Islands, Fiji, Kiribati, Marshall Islands, Nauru, Niue, Samoa, Solomon Islands, Tokelau, Tonga, Tuvalu and Vanuatu) is one such university, particularly due to its unique mission: To deliver cost-effective quality education online to students living in the remote Pacific islands spread across 33 million square kilometers of ocean more than three times the size of Europe. In an effort to fulfill its mission and meet the critical needs of remote students, the USP is currently working towards developing 10 online learning programs by 2018 (University of the South Pacific, 2013: p. 13).

Unfortunately, the constant rise in the price of publisher textbooks poses a major hurdle in the university's ambition to provide cost-effective tertiary education to students studying in the most remote places in the world. In fact, the cost of publishers' textbooks has risen a staggering $812 \%$ over the last 36 years (Perry, 2012), with growing evidence revealing that many students are unable to afford textbooks (Allen, 2011; Graydon, UrbachBuholz, \& Kohen, 2011; Rube, 2005). A recent survey (Senack, 2014) of 2039 university students reported that $65 \%$ of students decided not to purchase textbooks due to their expense. Most significantly, numerous studies have found that students who do not have their own textbook copy frequently fall behind, compromising their learning outcomes and increasing their probability of failing their course (Allen, 2011; Graydon et al., 2011; Morris-Babb \& Henderson, 2012; Senack, 2014).

Though rising prices continue to affect students to the extent where some forgo purchasing textbooks, an interesting paradox exists: textbooks are often a prescribed component of courses offered at the USP. Prasad and Usagawa (2014) estimate that a USP student spends close to \$200 on textbooks each semester, bringing annual textbook costs to $\$ 400$ per student. Indeed, research shows that students are opting out of purchasing prescribed textbooks despite knowing that doing so would negatively affect their grades (Senack, 2014). Remarkably, prescribed textbooks account for approximately 75 to 90 percent of course discourse (Stein, Stuen, Carnine, \& Long, 2001). With such a high percentage of textbook-based instruction and the fact that textbooks play a critical role in students' achievement, the need for a cost-effective solution to the problem of textbook affordability is urgently required at USP.

Recently, several textbook researchers (Allen, 2008b; Hilton \& Wiley, 2011; Okamoto, 2013; Senack, 2014) have asserted the potential of open textbooks as a solution to expensive commercially published textbooks. Senack estimates that open textbooks could save students around \$100 per course, a plausible assessment. For instance, British Columbia's open textbooks project has already saved students an average of \$146 each on their textbook costs (Government of British Columbia, 2014). Most importantly, research has shown that students who study with open textbooks perform as well on tests as do their peers who use traditional textbooks (Wiley, Hilton, Ellington, \& Hall, 2012). In the context of tertiary education, a traditional "textbook" is commonly understood as being instructional material used within tertiary education, delivered to the user on paper, in the form and binding produced and distributed by a publisher (Education for Change Ltd. \& University of Stirling, 2003: p. 11). Open textbooks "are similar to traditional textbooks in terms of content; however, they are generally available for free in digital format, along with low-cost print copies” (Hilton, Gaudet, Clark, Robinson, \& Wiley, 2013: p. 38). However, while open textbooks are digital textbooks, not all digital textbooks are open textbooks (i.e. free textbooks in digital formats). The term "digital" in "digital textbooks" means a textbook that is available in digital (or electronic) format such as HTML, EPUB, MOBI, OPF or PDF. Normally, digital textbooks are "consumed on a screen rather than on paper" (Nelson, 2008: p. 42).

It is important to point out that textbooks in digital formats are not merely digitized replicas of printed textbooks. With recent developments in new and affordable educational technologies, textbooks in digital forms increasingly enable positive impacts on publishing, delivery, learning and teaching. As such, open textbooks not only possess the strong advantage of being free, but they also offer further advantages over traditional printed textbooks such as:

- More features-open textbooks may include interactive learning functions such as bookmarks, highlighting, annotations, text searching, quizzes, and hyperlinks; multiple digital media such as text, pictures, audio, video, animation, and interactive simulation; and options to synchronize offline and online learning data, which may be used to analyze students' reading patterns to enable subsequent improvement of the text and pedagogical methods. 
- Better accessibility-open textbooks may be developed in a range of formats such as Web, EPub, PDF. This results in reduced physical size and weight, enabling increased portability and mobility, and provides options to print, read online and download for offline reading on various hardware devices such as a dedicated handheld device, a personal digital assistance (PDA), a mobile phone, or a desktop or laptop computer. The digital format reduces production and distribution time, and consequently facilities expeditious availability of texts that further support access.

- Greater flexibility-open textbooks may be updated quickly and provide access to the latest content. It "could be updated, say, to incorporate new knowledge. It could be improved as students and teachers develop better ways of expressing concepts or ordering learning objects. It could be localized or customized for a variety of learners, whether in different cultures or at different levels of education” (Matkin, 2009: p. 3).

Despite the abovementioned benefits, the adoption of digital textbooks has reportedly been much slower than anticipated (Allen, 2008a; Guthrie, 2012; Lee, 2010; Oliveira, 2012; Thomas, 2007). The reasons for this slow adoption vary, but 3 principal reasons emerge from literature.

To begin with, numerous studies have shown that students' attitudes and preferences toward printed books were more positive than toward digital textbooks (Armatus, Holt, \& Rice, 2003; Armstrong, 2008; BuzzettoMore, Sweat-Guy, \& Elobaid, 2007; Folb, Wessel, \& Czechowski, 2011; Levine-Clark, 2006; Li, Poe, Potter, Quigley, \& Wilson, 2011; McKnight \& Dearnley, 2003; Spencer, 2006; Woody, Daniel, \& Baker, 2010). Cuillier and Dewland (2014), for example, in their pilot study of digital textbook integration into a business course, found that almost $64 \%$ (23 out of 36) survey respondents preferred to read textbooks in print. Several themes consistently appear in literature on preferences for print format. These include less visual fatigue; more retention; greater comfort and relaxation; less anxiety; faster reading; and dependability and ease of use. However, unlike most commercial digital textbooks, open textbooks can be printed, thus resolving the concerns of those who prefer print format.

Next is the issue of digital textbook compatibility with hardware and software (Lee, Messom, \& Yau, 2013). A digital textbook has three elements: the digital textbook content file, software to read the file, and a hardware device to view it on (Cavanaugh, 2002). Compatibility depends on these three elements; in other words, "you need the right software to read the right format, and you need that software installed on a compatible hardware device” (Nix, 2010: para. 9). Actually, digital textbook content in various file formats should be accessible on various hardware devices (for example, PC, laptop, PDA, or a dedicated hand-held reading device) to suit students' reading preferences. However, not all devices are compatible with all digital textbook format options (Buell, 2013: para. 2). Anuradha and Usha (2006) claim that digital textbook adoption rates have been slow because of its availability over disparate formats which are often "incompatible and non-interoperable" (p. 49). In the same vein, Landoni and Hanlon (2007) and Nelson (2008) acknowledged the possibility that compatibility problems may be a major force in slowing digital textbook adoption. This view has been confirmed by several studies. For example, in their interview study of 180 students and 20 academic staff members eliciting opinions about the challenges facing digital textbook adoption across schools in Bandar Sunway in Malaysia, Lee et al., (2013) found the most common perceptions about digital textbook use were related to difficulties associated with compatibility of digital books technology. Teachers in their study commented, "E-textbook reader device and content format incompatibility will be a problem," and "[t]he 'format' war for e-textbooks is a hurdle that must be overcome", while one student commented that "I won't buy anything if it's not compatible with all of my devices" (p. 35).

Third is the problem driven by students' lack of contentment with digital textbook features. Brahme and Gabriel (2012) surveyed graduate students' experiences and preferences regarding digital textbooks. They reported that lack of digital textbook features such as note-taking and highlighting caused frustration to $63 \%$ of their participants. Brahme and Gabriel (2012) asserted that students are often frustrated with digital textbook features that do not satisfy their needs. In another major study of how students use browser-based digital books (not necessarily textbooks), Berg, Hoffmann, and Dawson (2010) found that many students were frustrated with the structure and functionality of digital book features as they did not function according to their expectation. The authors concluded that, while interactive features are an advantage digital books have over printed books, these features must function well and be easily understood by the users for digital books to be more widely accepted.

To conclude, the three root causes for the current slow adoption of digital textbooks are: Greater preferences for reading printed textbooks over digital ones; incompatibility with students preferred reading device(s); and incongruence of digital textbook features with students' expectations. Taken together, these findings indicate 
that successful adoption of digital textbooks is primarily dependent on student preferences.

How to apply the findings from these studies to the adoption and acceptance of open textbooks among students, however, remains unclear, as most previous studies have only focused on adoption of commercial digital textbooks, not open textbooks. Such findings are thus not applicable, especially since open textbooks are free and printable; cost savings and printing options may encourage students to choose open textbooks over traditional textbooks. Moreover, open textbook publishing currently lacks the established vigorous editorial mechanisms found in traditional publishing models, eliciting uncertainties about accuracy and reliability of the content (Educause, 2011), which may cause students to lean towards traditional textbooks. As such, students' preferences towards open textbook adoption-as opposed to commercial digital textbooks-remain unclear.

At the moment, USP is investigating possibilities to integrate open textbooks to its online courses in an effort to provide students with more affordable, interactive and flexible textbooks. In order to implement open textbooks effectively, it is vital for USP to craft clear strategies for the adoption of open textbooks for e-Learning. In this vein, prior consultation with students themselves is required as their preferences towards open textbook adoption and factors influencing their choices will provide valuable information in predicting their acceptance of open textbooks. Awareness of student preferences is also crucial since their academic success is at stake. With these concerns in mind, this study addressed four factors:

1) What are the implications of textbook costs on students' academic careers?

2) What are students' preferences and motivations for, and barriers against, open textbook adoption?

3) What are students' most desired digital features in open textbooks?

4) What are students' most preferred devices for accessing open textbooks?

\section{Methodology}

The positivist paradigm was adopted to answer the above research questions. A quantitative Web-based survey questionnaire partly making use of questions from 2012 Florida Student Textbook Survey (Florida Virtual Campus, 2012) was constructed in five sections: 1) demographics; 2) impacts of textbook costs; 3) open textbook adoption; 4) desired digital features; and 5) desired reading devices. Three experts verified content validity of the questionnaire, with the questionnaire modified based on their responses and comments. A conditional question was included in Section 3: If the respondent answered "yes for some of my courses" or "yes for all my courses" to open textbook adoption questions, they were taken to motivator question, while a "no", "maybe" or "undecided" response took them to barrier questions. A variety of question formats was used: forced choice, multiple choice, multiple select, rating, skip-logic, and Likert scale. The final questionnaire included 18 questions. To ensure reliability of the final version, test-retest reliability with a two-week interval was conducted on 7 students. The results obtained were subjected to Cronbach's alpha test, and the overall reliability of the final questionnaire reached $(r=0.84)$, which was acceptable to proceed with the survey. This study was conducted in accordance with all the requirements of ethical considerations. A self-selected sampling method was employed to generate a sample of students consisting of full-time and part-time students registered with the USP for academic year 2013. The questionnaire was distributed online via Google Forms and was made available for one month from mid-November to mid-December in 2013. All students were e-mailed regarding the anonymous survey, and one reminder was issued. E-mails that were returned as "undeliverable" were removed from the sample size. The total number of students able to see the invitation to complete the survey was approximately 13,000. 1138 questionnaires were received, and after rejecting 61 partially filled-in questionnaires, 1077 remained available for analysis. Thus, the response rate was $8 \%$. The data gathered via Google Forms were exported to MS-Excel for analysis based on the research questions. The results of the study are discussed in the next section.

\section{Results}

To ensure accurate interpretation, the Hilton et al., (2013: p. 38) definition of an open textbook as cited in the introduction to this paper was provided to respondents in the invitation e-mail to participate as well as in the survey. The data from the survey's quantitative questions were analyzed and are presented below.

\subsection{Demographics}

Of 1077 respondents, $45 \%$ were male $(n=489)$ and $55 \%$ were female $(n=588)$. The majority of the respon- 
dents, $90 \%(n=970)$, were undergraduate students, with only $10 \%(n=107)$ being postgraduate students. Of the total respondents, $82 \%$ ( $n=888)$ were full-time and $18 \%(n=189)$ were part-time students. $70 \%$ of the respondents were less than 25 years old, 26\% were between 26 and 40 years old, and the remaining $4 \%$ represented age groups older than 41 . The students were categorized by their disciplines based on three different faculties in the USP, with the majority of students $(n=429)$ from Faculty of Business and Economics followed by Faculty of Science, Technology and Environment $(n=372)$, and Faculty of Arts, Law and Education $(n=276)$.

\subsection{Frequency of Buying Prescribed Textbooks}

Students were asked to give an indication of how often they bought prescribed textbooks. As Table 1 demonstrates, 484 of the 1077 respondents reported purchases very frequently or frequently, 331 bought occasionally, 183 rarely bought, and 79 reported that they never purchased prescribed textbooks.

\subsection{Number of Prescribed Textbooks Bought in Semester 2, 2013}

All the respondents $(n=1077)$ were asked how many prescribed textbooks they purchased for Semester 2, 2013. $74 \%(n=793)$ reported buying at least one prescribed textbook, while $284(26 \%)$ students indicated that they did not purchase any textbook for Semester 2, 2013. Table 2 presents a breakdown of textbooks purchased in Semester 2, 2013. As illustrated, 793 students purchased a total of 1970 books. The number of textbooks bought by an individual ranged from 1 to 5 textbooks, with the mode falling in 2 .

\subsection{Textbook Expenditure for Semester 2, 2013}

Those students $(n=793)$ who reported textbook purchase were asked to estimate the total Fijian dollar (1FJD = 0.55 USD) amount of their purchase for Semester 2, 2013. Table 3 demonstrates the respondents' replies, in

Table 1. Prescribed textbook purchase frequency.

\begin{tabular}{cc}
\hline How often do you buy prescribed textbooks? & Frequency \\
\hline Very frequently & 191 \\
Frequently & 293 \\
Occasionally & 331 \\
Rarely & 183 \\
Never & 79 \\
\hline
\end{tabular}

Table 2. Number of prescribed textbooks purchased.

\begin{tabular}{ccc}
\hline How many prescribed textbooks did you buy for Semester 2, 2013? & Frequency & Percentage \\
\hline None & 284 & 26 \\
One & 186 & 17 \\
Two & 227 & 21 \\
Three & 216 & 20 \\
Four & 138 & 26 \\
Five & & 26 \\
\hline
\end{tabular}

Table 3. Semester 2, 2013 textbook expenses.

\begin{tabular}{ccc}
\hline How much did you spend on your textbooks for Semester 2, 2013? & Frequency & 247 \\
FJD000-100 & 132 \\
FJD101-200 & 177 \\
FJD201-300 & 106 & 17 \\
FJD301-400 & 116 \\
FJD401-500 & 15 \\
More than FJD500 & 15 \\
\hline
\end{tabular}


terms of frequency and percentage of students by expenditure category. According to the results, $69 \%$ of the students reported spending over FJD200 on textbooks during Semester 2, 2013.The three most common expenditure categories were FJD000-100 (31\%), followed by FJD201-300 (22\%), and, in third place, FJD101-200 range chosen by $17 \%(n=132)$ of respondents. The most striking result to emerge from the data is that $30 \%(n=237)$ of the respondents spent more than FJD300 on textbooks.

\subsection{Scholarship for Textbook Expenses}

Those students ( $n=793$ ) who had purchased textbooks were asked to clarify whether they were on scholarship during Semester 2, 2013. Remarkably, 650 (82\%) of the 793 students who had bought textbooks reported that they were on scholarship during the second semester of 2013. Scholarship recipients $(n=650)$ were then asked to indicate the percentage of their textbook costs covered by the scholarship. 22\% reported that their scholarship did not cover any of the textbook costs, $23 \%$ said that all their textbooks costs was covered by the scholarship, and $57 \%$ indicated that a portion of their textbooks costs was covered by the scholarship (Table 4).

\subsection{Methods of Textbook Purchase}

Students $(n=793)$ who had purchased textbooks were asked to select their methods of textbook purchase. Taking into account that an individual would buy more than one text (see Table 2), multiple-select was allowed. The results, as shown in Table 5, indicate that the most common method of purchase was buying new, printed textbooks from the campus bookshop (64\%), which was followed by buying used printed textbooks (21\%). The least popular methods of purchase were buying digital textbook with permanent access (8\%) and buying digital versions with temporary access (7\%). The single most striking observation to emerge from the data comparison was that $85 \%$ of the students purchased printed textbooks, while only $15 \%$ opted for digital versions.

\subsection{Reasons for Not Buying a Textbook}

Those students $(n=284)$ who reported not purchasing a textbook were asked to select cause(s) from a prepared list of reasons for not doing so. The list of reasons, frequency, and percentage is presented in Table 6. As illustrated, the four most commonly cited reasons for not buying a textbook were unaffordability (42\%), no textbooks prescribed (15\%), using a classmate's copy (14\%), and photocopying required chapters from the textbook (10\%).

\begin{tabular}{|c|c|c|}
\hline $\begin{array}{l}\text { What percentage of your textbook expense was covered by scholarship for } \\
\text { Semester 2, 2013? }\end{array}$ & Frequency & Percentage \\
\hline None & 140 & 22 \\
\hline Less than $25 \%$ & 120 & 18 \\
\hline $26 \%$ to $50 \%$ & 130 & 20 \\
\hline $51 \%$ to $75 \%$ & 67 & 10 \\
\hline $76 \%$ to $99 \%$ & 46 & 7 \\
\hline All textbook expense & 147 & 23 \\
\hline
\end{tabular}

Table 5. Textbook purchase method.

\begin{tabular}{ccc}
\hline $\begin{array}{c}\text { For Semester 2, 2013, how did you purchase your textbooks? } \\
\text { Please select all that apply. }\end{array}$ & Frequency & Percentage \\
\hline I purchased new print versions from the campus bookshop. & 707 \\
I purchased used print versions from former students. & 231 \\
I purchased digital textbooks-temporary ownership license. & 75 & 21 \\
I purchased digital textbooks-permanent access. & 90 \\
\hline
\end{tabular}


Table 6. Reasons for not buying a textbook.

\begin{tabular}{lcc}
\hline $\begin{array}{l}\text { Which of the following reason(s) explain why you did not buy a } \\
\text { textbook in Semester 2, 2013? Please select all that apply. }\end{array}$ & Frequency & Percentage \\
\hline Not prescribed for the course(s) I took. & 56 & 15 \\
Too expensive; not able to afford it. & 160 & 42 \\
Borrowed the textbook from my classmates. & 32 & 14 \\
Borrowed the textbook from the campus library reserve shelf. & 22 & 3 \\
Photocopied the whole textbook. & 38 & 10 \\
Photocopied the required chapters from the textbook. & 17 & 5 \\
\hline
\end{tabular}

\subsection{Textbook Cost Consequences}

The respondents ( $n=1077$ ) were asked to rate the effects of high textbook costs on their academic career (see Table 7). As shown, students indicated that the high cost of textbooks has caused them to, frequently, occasionally, or seldom: not purchase prescribed textbook (65\%), submit assigned activities late (57\%), earn poor grade (56\%), take fewer courses (44\%), fail a course (39\%), not register for a course (31\%), drop a course (28\%), or withdraw from a course (26\%).

\subsection{Actions Taken to Reduce Textbook Cost}

Table 8 shows the various actions respondents $(n=1077)$ took in order to reduce costs of textbooks. The vast majority of the students (72.2\%) reported taking one or more measures to reduce the costs of their textbooks. Among the 10 actions to reduce textbook costs, the 3 most frequently reported were: buying used copies from former students (81.7\%), using a reserve copy from the campus library (81.2\%), and sharing books with classmates $(81.1 \%)$.

\subsection{Intention to Adopt Open Textbooks}

Table 9 presents the distribution of student responses on their willingness to use open textbooks in the future given the choice of free access to digital versions and/or print at your own cost. Of the 1077 students who responded to the survey, $69 \%(n=743)$ said they would use open textbooks for some or all of their courses, while only 3\% (36/1077) reported that they had no intention of using open textbooks. The combined total of $28 \%$ : "maybe" (21\%) and “undecided" (7\%), indicated respondents' indecisiveness on whether they would use open textbooks in the future.

\subsection{Motivations for Adopting Open Textbooks}

Only those students $(n=743)$ who intended to use open textbooks for some or all of their courses were asked to rate motives that influenced their decision. These students were asked to rate 10 motivator items on a 5-point Likert-type scale ranging from 0 to 4 for each of the motivator items, where 0 represented a motive that had "no influence" on their decision and 4 represented a "very influential" motive. Each score on the Likert scale was then converted to a mean motivator score $(0=0,1=25,2=50,3=75,4=100)$, so that higher scores indicated stronger motivation. Table 10 illustrates the rank order and motivator strength (mean) of these 10 motivators. As illustrated, the motivator strength ranged from a high of 89.0 for the item 'They are freely available' to a low of 58.1 for the item "They are visually appealing”.

\subsection{Barriers to Adopting Open Textbooks}

Those indecisive students $(n=298)$ and the students who were not interested $(n=36)$ in using open textbooks were asked to rate the strength of each barrier from a set of 6 potential barriers to open textbooks adoption on a Likert-type scale with scores ranging from 0 (no influence) to 4 (very influential). All the scores were transformed to a 0 - 100 scale $(0=0,1=25,2=50,3=75,4=100)$. Table 11 shows the rank order and barrier 
Table 7. Textbook cost consequences.

\begin{tabular}{lccccccccc}
\hline \multicolumn{1}{c}{ Consequence } & \multicolumn{3}{c}{ Never } & \multicolumn{2}{c}{ Seldom } & \multicolumn{2}{c}{ Occasionally } & \multicolumn{2}{c}{ Frequently } \\
\cline { 2 - 9 } & $n$ & $\%$ & $n$ & $\%$ & $n$ & $\%$ & $n$ & $\%$ \\
\hline Take a fewer courses. & 603 & 56 & 151 & 14 & 129 & 12 & 194 & 18 \\
Not to register for a specific course. & 743 & 69 & 129 & 12 & 97 & 9 & 108 & 10 \\
Drop a course. & 775 & 72 & 140 & 13 & 75 & 7 & 86 & 8 \\
Withdraw from a course. & 797 & 74 & 118 & 11 & 75 & 7 & 86 & 8 \\
Earn a poor grade because I could not afford the & 474 & 44 & 183 & 17 & 194 & 18 & 226 & 21 \\
textbook. & 657 & 61 & 162 & 15 & 118 & 11 & 140 & 13 \\
Fail a course because I could not afford the textbook. & 463 & 43 & 151 & 14 & 194 & 18 & 269 & 25 \\
Submit my assigned activities late because I did not & 463 \\
have the prescribed textbook. & 377 & 35 & 129 & 12 & 162 & 15 & 409 & 38 \\
Not purchase the required textbook. & & & & & & &
\end{tabular}

Table 8. Actions taken to reduce textbook costs.

\begin{tabular}{|c|c|c|c|c|}
\hline \multirow{2}{*}{ Action } & \multicolumn{2}{|c|}{ Yes } & \multicolumn{2}{|c|}{ No } \\
\hline & $n$ & $\%$ & $n$ & $\%$ \\
\hline Make no attempt to reduce textbook cost. & 299 & 27.8 & 778 & 72.2 \\
\hline Share books with classmates. & 873 & 81.1 & 204 & 18.9 \\
\hline $\begin{array}{l}\text { Buy used or new books online from a source other than the campus } \\
\text { bookshop. }\end{array}$ & 657 & 61.0 & 420 & 39.0 \\
\hline Buy a digital version of a textbook. & 585 & 54.3 & 492 & 45.7 \\
\hline Buy used copies from former students. & 880 & 81.7 & 197 & 18.3 \\
\hline Do not purchase the prescribed textbook. & 790 & 73.4 & 287 & 26.6 \\
\hline Use a reserve copy from the campus library. & 875 & 81.2 & 202 & 18.8 \\
\hline Photocopy only the chapters needed for the course. & 798 & 74.1 & 279 & 25.9 \\
\hline Photocopy the whole textbook. & 524 & 48.7 & 553 & 51.3 \\
\hline Sell used books. & 753 & 69.9 & 324 & 30.1 \\
\hline
\end{tabular}

Table 9. Intention to use open textbooks.

\begin{tabular}{ccc}
\hline Intention to use open textbook in the future & Frequency & Percentage \\
\hline No & 36 & 3 \\
Maybe & 227 & 71 \\
Undecided & 345 & 7 \\
Yes, for some of my courses & 398 & 32 \\
Yes, for all my courses & & 37 \\
\hline
\end{tabular}

strength (mean) of these items.

\subsection{Preferred Digital Features}

To elucidate the most preferred digital features in open textbooks, all those students $(n=743)$ who had indicated their willingness to use open textbooks for some or all their courses were asked to rate the preference of 10 features on a 5-point Likert scale (where a score of "0" was “least preferred” and "5" "most preferred”). Mean was calculated by converting all the scores to a 0 - 100 scale, in a manner that higher mean scores indicate greater preference. Table 12 depicts the rank and mean of the 10 digital features provided in the list. 
Table 10. Motivators to use open textbooks.

\begin{tabular}{|c|c|c|}
\hline Rank & Motivators & Motivator strength (mean) \\
\hline 1 & They are freely available. & 89.0 \\
\hline 2 & They can be self-printed and read. & 87.2 \\
\hline 3 & They have interactive features that are not available in printed books (e.g. search functions). & 83.5 \\
\hline 4 & $\begin{array}{l}\text { They have features which are in printed books but easier to use in digital version } \\
\text { (e.g. hyperlinked table of contents). }\end{array}$ & 78.3 \\
\hline 5 & Theyhave greater mobility and areconvenientto carry. & 77.6 \\
\hline 6 & They are easily portable and can be read on various reading devices. & 76.6 \\
\hline 7 & They can be downloaded to a personal device and read offline. & 75.7 \\
\hline 8 & They can be read online. & 74.3 \\
\hline 9 & They are easy to use. & 70.3 \\
\hline 10 & They are visually appealing. & 58.1 \\
\hline
\end{tabular}

\section{Table 11. Barriers to use open textbooks.}

\begin{tabular}{|c|c|c|}
\hline Rank & Barriers & Barrier strength (mean) \\
\hline 1 & I prefer reading printed materials. & 71.3 \\
\hline 2 & I am afraid digital textbooks may not be compatible with all my reading devices. & 63.7 \\
\hline 3 & I am worried about the quality of content. & 63.3 \\
\hline 4 & I do not have experience in using digital textbooks. & 62.7 \\
\hline 5 & I am not confident with using digital textbooks. & 56.6 \\
\hline 6 & I do not have access to technology required to take advantage of digital textbooks. & 43.6 \\
\hline
\end{tabular}

Table 12. Preferred digital features.

\begin{tabular}{ccc}
\hline Rank & Features & Mean \\
\hline 1 & Hyperlinked table of contents & 81.5 \\
2 & Adding notes & 81.2 \\
3 & Bookmarking & 80.5 \\
4 & Searching within the textbook & 80.3 \\
5 & Provides links to websites & 80.1 \\
6 & Copying and pasting & 79.0 \\
7 & Incorporates videos, figures, diagrams, or images & 77.9 \\
9 & Highlighting & 76.5 \\
\hline
\end{tabular}

\subsection{Preferred Reading Devices}

Table 13 shows preferences for reading devices for open textbooks as expressed by those students $(n=743)$ who were in favor of using open textbooks for some or all their courses in the future. As shown, from a prespecified list of 4 common reading devices, the largest proportion of students (64\%) preferred laptops; when combined with other mobile devices such as tablets (15\%) and mobile phones (2\%), $81 \%$ of the students preferred to access open textbooks through a mobile device. 
Table 13. Most preferred reading device.

\begin{tabular}{ccc}
\hline Device & Frequency & Percentage \\
\hline Laptop & 476 & 64 \\
Desktop computer & 141 & 19 \\
Tablet (iPad, Galaxy, other) & 111 & 15 \\
Mobile phone & 15 & 2 \\
\hline
\end{tabular}

\section{Discussion}

This study surveyed three factors affecting USP students’ prescribed textbook buying behaviors and their preferences towards open textbooks adoption in place of traditional publisher texts as prescribed textbooks for their online courses: Cost, digital features, and preferred reading devices. The current study found that 814 of the 1077 students very frequently, frequently or occasionally bought prescribed textbooks. Similarly, in an earlier study by Carpenter, Bullock, and Potter (2006), almost three quarters of students reported buying textbooks that had been prescribed to them. As a result of their research, they concluded that the probability of a student buying a prescribed textbook depends of the strength of the endorsement given by their course lecturers. This also seems to a determinant of USP students' purchase decisions for prescribed textbooks. Of the 1077 students who took part in the survey, the majority, 74\% $(n=793)$, indicated buying at least one prescribed textbook during Semester 2, 2013. The purchasing quantity ranged from 1 to 5 prescribed textbooks, with the mode falling in 2. In part, this wide array of purchases may be due to the number of courses taken by each student. The textbook expenditure reported for Semester 2, 2013, ranged from FJD000-100 category to over FJD500, with approximately one-third of those who made purchase spent over FJD300. Interestingly, 650 out of 793 students who bought textbooks were on scholarship. From the 650 scholarship recipients, $23 \%$ received full funding for textbook expenses, 57\% got partial grant, and only 22\% did not receive any financial aid for their textbook expenses. What is surprising is that amongst those students $(n=793)$ who purchased textbooks, the majority of them $(64 \%)$ received some financial grant towards their textbook expenses. The data suggest that students who do not receive any financial support towards textbook expenses are less likely to purchase textbooks. It is perhaps not surprising that $42 \%$ of those students who reported not buying a textbook said they had not purchased one or more textbooks because the cost was too high. Three other common reasons for not buying a textbook included: textbook not required for a course (15\%), borrowing a classmate's textbook (14\%), and photocopying required chapters from the textbook (10\%). The five most detrimental effects expensive textbooks had on students' academic careers were revealed as inability to purchase prescribed textbooks, late submission of assigned activities due to no personal copy of prescribed text, poor grades, fewer courses, and course failure. This clearly indicates that high textbook costs have a negative impact of students' academic careers. Given the adverse effects of expensive textbooks, students were asked if they did anything to reduce their textbook expenses. It is not surprising that a large majority (72.2\%) of respondents indicated that they used more than one strategy to save money on textbook cost. The most popular method reported was buying used textbooks, with $81.7 \%$ of respondents indicating that they utilized this method. This is in line with the recent finding by the AdHoc Senate Committee on Student Textbook Savings, where 81.4\% of the respondents reported buying used textbooks (AdHoc, 2014). The three most popular methods reported were sharing classmate's books, using a library copy, and buying used textbooks.

In response to the question of whether the students are willing to use open textbooks in the future for their online courses, the majority responded in the positive, "Yes, for some of my courses" (32\%) or "Yes, for all my courses" (37\%). These results showed that free availability of open textbooks was the highest rated motive behind these willing students' intention to use open textbooks in the future. This was expected since reduced cost is the most commonly reported benefit of open textbooks (Hilton, Robinson, Wiley, \& Ackerman, 2014; Wiley et al., 2012). The next most highly rated motivator was ability to self-print. Again, this comes as no surprise as most previous studies have consistently found that students prefer to read printed rather than on-screen materials (Buzzetto-More et al., 2007; Spencer, 2006; Woody et al., 2010). Interactive features, which are not available in printed books, were ranked at third position. Concerning barriers to open textbooks adoption: Preference for reading printed materials, concerns about compatibility, and worries about quality of content were ranked as the 
top-three barriers to adoption of open textbooks by those students who were not in favor or undecided about using open textbooks. The top two barriers are commonly cited barriers to adoption of textbooks in digital formats (as identified in the introduction to this paper); however, concerns regarding quality of content have also emerged as a strong barrier that may overshadow open textbooks free of price. In connection with quality, Cragun (2007) asked his students if they preferred a more developed textbook that costs money or a free textbook that covered just what they needed to know for the course. Students preferred using a free textbook. Cragun remarked that free does not always mean the open textbook is good, but he recognized quality is important and that more people collaborating in development will help ensure this. In the final part of the paper, he writes: "My students clearly liked the text, despite its flaws, but this was likely due-in large part-to the text being free" (Cragun, 2007: p. 11). The results of Cragun's study showed that students liked the zero dollar cost and did not worry that the textbook was incomplete as long as the textbook covered the course learning contents.

With regard to student preferences for digital features, hyperlinked table of contents was the most preferred feature with a mean of 81.5. The next most preferred features, in descending order, were adding notes, bookmarking, searching within the textbook, and links to websites (all these features has mean above 80). Several research studies (Behler \& Lush, 2010; Chong, Lim, \& Ling, 2009; Cuillier \& Dewland, 2014) have shown that these features were atop the wish list of students. That the majority of students in this and other studies strongly prefer these features substantiates making these features richer and standardized across digital textbook technology. According to Behler and Lush (2010), digital textbook features are far from where they need to be to allow digital textbooks to replace traditional books. Concurring with Behler and Lush (2010), Philip and Moon (2013) purported that there is a need for significant improvements in the features of digital textbooks for them to be widely adopted. This further validates the call for the development of better and consistent digital textbook features.

On the question of students' most preferred device for reading open textbooks, most (64\%) indicated laptops, $19 \%$ desktop computers, $15 \%$ tablets, and $2 \%$ mobile phones; consequently, $81 \%$ of the students preferred to access open textbooks through a mobile device. This finding is consistent with recent studies of digital textbooks such as Rockinson-Szapkiw, Courduff, Carter, and Bennett (2013), Cuillier and Dewland (2014), and Hwang, Kim, Lee, and Kim (2014). The current study found that the least preferred device was mobile phone. This finding is not surprising given results from prior studies that have found this type of technology has not shown great popularity for the purpose of digital textbook reading (Croft \& Davis, 2010; Zimerman, 2011). Some authors (e.g. Zimerman, 2011) have speculated that, with appropriate software, mobiles phones could double as a viable reading device, particularly since most students have mobile phones. As such, it is important to develop platform-independent open textbooks that are accessible through any reading device with a simple browser-based interface. Finally, the response rate to the survey was limited and much lower than anticipated, which might limit the generalizability of findings to the target population. However, the study was feasible to conduct as a starting point for further work.

\section{Conclusion and Future Directions}

This study was concerned with USP students' preferences towards adoption of open textbooks for online courses; however, the results should be applicable also to other USP course modes (blended, print and face-to-face). The results of the current study are extremely encouraging, with a good percentage (69\%) of the surveyed students indicating their willingness to use open textbooks for some or all of their courses, though not all students were keen in using open textbooks. But like any other technological innovation in education, with continued usage, students are likely to gradually get more familiar and confident in using textbooks in digital formats. Hoseth and Merinda (2012) in their paper similarly concluded that participants in their study clearly expressed the need to adapt to change and switch to digital textbook formats, and successively becoming more familiar with them over time. This is in consonance with Chou (2014: p. 16) when he concludes that, "When students are given time and opportunities to read e-books, they are likely to develop e-book reading habits. It would be a pity if we gave up providing students e-books merely because of their initial negative attitudes.”

In consideration of the above findings, the study recommends the viability of open textbooks. Expensive traditional textbooks will need to be replaced with open textbooks as prescribed textbooks for USP courses. Clearly, this will be no mean feat. Future work will involve: 1) Identifying USP teachers willing to collaborate with the primary author in the development of custom-built OER derived open textbooks; 2) Developing an open text- 
book learning analytics system; 3) Piloting an open textbook over a semester; 4) Evaluating an open textbook and the analytics system; 5) Documenting the development processes; and 6) Disseminating the outcomes through conferences and journals as well as focused events and workshops within USP. Considering the convincing results and suggested research directions, there is hope that open textbooks will replace their traditional counterparts as prescribed texts and in process benefit USP students.

\section{Acknowledgements}

Part of this work was supported by Grant-in-Aid for Scientific Research 25280124. Deepak Prasad is a member of the Global OER Graduate Network (GO-GN), http://www.ou.nl/go-gn.

\section{References}

AdHoc Senate Committee on Student Textbook Savings (2014). Recommendations to Save on Student Textbooks Costs. http://www.lib.utah.edu/pdf/TextbookSavingsReport_FINAL.pdf

Allen, N. (2008a). Course Correction: How Digital Textbooks Are off Track and How to Set Them Straight (pp. 1-21). http://www.immagic.com/eLibrary/ARCHIVES/GENERAL/ST_PIRGS/S080826A.pdf

Allen, N. (2008b). Digital Textbooks: A Student Perspective. New England Journal of Higher Education, $23,32$.

Allen, N. (2011). High Prices Prevent College Students from Buying Assigned Textbooks. Student PIRGs. http://www.studentpirgs.org/news/ap/high-prices-prevent-college-students-buying-assigned-textbooks

Anuradha, K. T., \& Usha, H. S. (2006). Use of E-Books in an Academic and Research Environment: A Case Study from the Indian Institute of Science. Program, 40, 48-62. http://dx.doi.org/10.1108/00330330610646807

Armatus, C., Holt, D., \& Rice, M. (2003). Impacts of an On-Line-Supported, Resource-Based Learning Environment: Does One Size Fit All? Distance Education, 24, 140-158.

Armstrong, C. (2008). Books in a Virtual World: The Evolution of the E-Book and Its Lexicon. Journal of Librarianship and Information Science, 40, 193-206. http://dx.doi.org/10.1177/0961000608092554

Behler, A., \& Lush, B. (2010). Are You Ready for E-Readers? The Reference Librarian, 52, 75-87. http://dx.doi.org/10.1080/02763877.2011.523261

Berg, S. A., Hoffmann, K., \& Dawson, D. (2010). Not on the Same Page: Undergraduates’ Information Retrieval in Electronic and Print Books. The Journal of Academic Librarianship, 36, 518-525. http://dx.doi.org/10.1016/j.acalib.2010.08.008

Brahme, M., \& Gabriel, L. (2012). Are Students Keeping up with the E-Book Evolution? Are E-Books Keeping up with Students' Evolving Needs? Distance Students and E-Book Usage, a Survey. Journal of Library \& Information Services in Distance Learning, 6, 180-198. http://dx.doi.org/10.1080/1533290X.2012.705109

Buell, C. (2013). E-Textbook Matchmaking: Assessing Compatibility between Hardware and Software. http://edcetera.rafter.com/e-textbook-matchmaking-assessing-compatibility-between-hardware-and-software/

Buzzetto-More, N., Sweat-Guy, R., \& Elobaid, M. (2007). Reading in a Digital Age: E-Books Are Students Ready for This Learning Object? Interdisciplinary Journal of Knowledge and Learning Objects, 3, 239-250.

Carpenter, P., Bullock, A., \& Potter, J. (2006). Textbooks in Teaching and Learning. Brookes eJournal of Learning and Teaching, 2, No. 1. http://bejlt.brookes.ac.uk/paper/textbooks_in_teaching_and_learning-2/

Cavanaugh, T. (2002). Ebooks and Accommodations: Is There the Future. Teaching Exceptional Children, 34, 56-61.

Chong, P. F., Lim, Y. P., \& Ling, S. W. (2009). On the Design Preferences for Ebooks. IETE Technical Review, $26,213-222$. http://dx.doi.org/10.4103/0256-4602.50706

Chou, I. C. (2014). Reading for the Purpose of Responding to Literature: EFL Students' Perceptions of E-Books. Computer Assisted Language Learning, 1-20. http://dx.doi.org/10.1080/09588221.2014.881388

Cragun, R. T. (2007). The Future of Textbooks? Electronic Journal of Sociology. http://www.sociology.org/content/2007/ cragun futureoftextbooks.pdf

Croft, R., \& Davis, C. (2010). E-Books Revisited: Surveying Student E-Book Usage in a Distributed Learning Academic Library 6 Years Later. Journal of Library Administration, 50, 543-569. http://dx.doi.org/10.1080/01930826.2010.488600

Cuillier, C. A., \& Dewland, J. C. (2014). Understanding the Key Factors for E-Textbook Integration into a Business Course: A Case Study. Journal of Business \& Finance Librarianship, 19, 32-60. http://dx.doi.org/10.1080/08963568.2013.824338

Education for Change Ltd., \& University of Stirling (2003). A Strategy and Vision for the Future for Electronic Textbooks in UK Further and Higher Education. 
http://www.jisc.ac.uk/uploaded_documents/Annex_E_E_Textbooks_Strategy_final_report.pdf

Educause (2011). 7 Things You Should Know about Open Textbook Publishing. http://net.educause.edu/ir/library/pdf/eli7070.pdf

Florida Virtual Campus (2012). 2012 Florida Student Textbook Survey. Tallahassee. http://www.openaccesstextbooks.org/pdf/2012 Florida Student Textbook Survey.pdf

Folb, B. L., Wessel, C. B., \& Czechowski, L. J. (2011). Clinical and Academic Use of Electronic and Print Books: The Health Sciences Library System E-Book Study at the University of Pittsburg. Journal of the Medical Library Association: JMLA, 99, 218-228. http://dx.doi.org/10.3163/1536-5050.99.3.009

Government of British Columbia (2014). Students Saving Money with Open Textbooks. http://www.newsroom.gov.bc.ca/2014/01/students-saving-money-with-open-textbooks.html

Graydon, B., Urbach-Buholz, B., \& Kohen, C. (2011). A Study of Four Textbook Distribution Models. Educause Quarterly, 34, 1-11. http://www.educause.edu/ero/article/study-four-textbook-distribution-models

Guthrie, K. M. (2012). Will Book Be Different? Journal of Library Administration, 52, 353-369. http://dx.doi.org/10.1080/01930826.2012.700805

Hilton, J. L., \& Wiley, D. (2011). Open-Access Textbooks and Financial Sustainability: A Case Study on Flat World Knowledge. The International Review of Research in Open and Distance Learning, 12, 18-26.

Hilton, J. L., Gaudet, D., Clark, P., Robinson, J., \& Wiley, D. (2013). The Adoption of Open Educational Resources by One Community College Math Department. The International Review of Research in Open and Distance Learning, 14, 37-50.

Hilton, J. L., Robinson, T. J., Wiley, D., \& Ackerman, J. D. (2014). Cost-Savings Achieved in Two Semesters through the Adoption of Open Educational Resources. International Review of Research in Open Distance Learning, 15, 67-84.

Hoseth, A., \& Merinda, M. (2012). Perspectives on E-Book from Instructors and Students in the Social Sciences. Reference \& User Services Quarterly, 51, 278-288. http://dx.doi.org/10.5860/rusq.51n3.278

Hwang, J. Y., Kim, J., Lee, B., \& Kim, J. H. (2014). Usage Patterns and Perception toward E-Books: Experiences from Academic Libraries in South Korea. The Electronic Library, 32, 522-541. http://dx.doi.org/10.1108/EL-11-2012-0150

Landoni, M., \& Hanlon, G. (2007). E-Books Reading Groups: Interacting with E-Books in Public Libraries. The Electronic Library, 25, 599-612. http://dx.doi.org/10.1108/02640470710829578

Lee, H. J., Messom, C., \& Yau, K. A. (2013). Can an Electronic Textbooks Be Part of K-12 Education? Challenges, Technological Solutions and Open Issues. The Turkish Online Journal of Educational Technology, 12, 32-44.

Lee, M. C. (2010). Explaining and Predicting Users' Continuance Intention toward E-Learning: An Extension of the Expectation-Confirmation Model. Computers \& Education, 54, 506-516. http://dx.doi.org/10.1016/j.compedu.2009.09.002

Levine-Clark, M. (2006). Electronic Book Usage: A Survey at the University of Denver. Collection Building, 26, 7-14. http://dx.doi.org/10.1108/01604950710721548

Li, C., Poe, F., Potter, M., Quigley, B., \& Wilson, J. (2011). UC Libraries Academic E-Book Usage Survey, Springer EBook Pilot Project. http://www.cdlib.org/services/uxdesign/docs/2011/academic ebook usage survey.pdf

Matkin, G. W. (2009). Open Learning: What Do Open Textbooks Tell Us about the Revolution in Education? In Center for Studies in Higher Education, Research \& Occasional Paper Series: CSHE.1.09 (pp. 1-8). Berkeley, CA: University of California. http://cshe.berkeley.edu/sites/default/files/shared/publications/docs/ROPs-Matkin-OpenLearning-03-31-09.pdf

McKnight, C., \& Dearnley, J. (2003). Electronic Book Use in a Public Library. Journal of Librarianship and Information Science, 35, 235-242. http://dx.doi.org/10.1177/0961000603035004003

Morris-Babb, M., \& Henderson, S. (2012). An Experiment in Open-Access Textbook Publishing: Changing the World One Textbook at a Time. Journal of Scholarly Publishing, 43, 148-155. http://dx.doi.org/10.3138/jsp.43.2.148

Nelson, M. R. (2008). E-Books in Higher Education: Nearing the End of an Era of Hype? Educause Review, 43, 40-56.

Nix, L. (2010). Ebook Formats: The Basics. http://goldenorbcreative.wordpress.com/2010/09/02/ebook-formats-the-basics/

Okamoto, K. (2013). Making Higher Education More Affordable, One Course Reading at a Time: Academic Libraries as Key Advocates for Open Access Textbooks and Educational Resources. Public Services Quarterly, 9, 267-283. http://dx.doi.org/10.1080/15228959.2013.842397

Oliveira, S. M. (2012). E-Textbooks Usage by Students at Andrews University: A Study of Attitudes, Perceptions, and Behaviors. Library Management, 33, 536-560. http://dx.doi.org/10.1108/01435121211279894

Perry, M. (2012). The College Textbook Bubble and How the “Open Educational Resources” Movement Is Going up against the Textbook Cartel. American Enterprise Institute.

http://www.aei-ideas.org/2012/12/the-college-textbook-bubble-and-how-the-open-educational-resources-movement-is-goi ng-up-against-the-textbook-cartel/

Philip, G. C., \& Moon, S. Y. (2013). An Investigation of Student Expectation, Perceived Performance and Satisfaction of 
E-Textbooks. Journal of Information Technology Education: Innovations in Practice, 12, 287-298.

Prasad, D., \& Usagawa, T. (2014). Towards Development of OER Derived Custom-Built Open Textbooks: A Baseline Survey of University Teachers at the University of the South Pacific. The International Review of Research in Open and Distance Learning, 14, 226-247.

Rockinson-Szapkiw, A. J., Courduff, J., Carter, K., \& Bennett, D. (2013). Electronic versus Traditional Print Textbooks: A Comparison Study on the Influence of University Students’ Learning. Computers \& Education, 63, 259-266.

http://dx.doi.org/10.1016/j.compedu.2012.11.022

Rube, K. (2005). Ripoff 101: How the Publishing Industry’s Practices Needlessly Drive up Textbook Costs: A National Survey of Textbook Prices (2nd ed.). Washington DC. http://www.studentpirgs.org/sites/student/files/reports/ripoff-101-2nd.pdf

Senack, E. (2014). Fixing the Broken Textbook Market: How Students Respond to High Textbook Costs and Demand Alternatives. Washington DC. http://www.washpirg.org/sites/pirg/files/reports/1.27.14 Fixing Broken Textbooks Report.pdf

Spencer, C. (2006). Research on Learners’ Preference for Reading from a Printed Text or from a Computer Screen. Journal of Distance Education, 21, 33-50.

Stein, M., Stuen, C., Carnine, D., \& Long, R. (2001). Textbook Evaluation and Adoption. Reading \& Writing Quarterly, 17, 5-23. http://dx.doi.org/10.1080/105735601455710

Thomas, S. E. (2007). Another Side of the E-Book Puzzle. Indiana Libraries, 26, 39-45.

University of the South Pacific (2013). Strategic Plan 2013-2018. Suva. http://www.usp.ac.fj/index.php?id=12556

Wiley, D., Hilton, J. L., Ellington, S., \& Hall, T. (2012). A Preliminary Examination of the Cost Savings and Learning Impacts of Using Open Textbooks in Middle and High School Science Classes. The International Review of Research in Open and Distance Learning, 13, 262-276.

Woody, W. D., Daniel, D. B., \& Baker, C. A. (2010). E-Books or Textbooks: Students Prefer Textbooks. Computers \& Education, 55, 945-948. http://dx.doi.org/10.1016/j.compedu.2010.04.005

Zimerman, M. (2011). E-Readers in an Academic Library Setting. Library Hi Tech, 29, 91-108. http://dx.doi.org/10.1108/07378831111116930 
Scientific Research Publishing (SCIRP) is one of the largest Open Access journal publishers. It is currently publishing more than 200 open access, online, peer-reviewed journals covering a wide range of academic disciplines. SCIRP serves the worldwide academic communities and contributes to the progress and application of science with its publication.

Other selected journals from SCIRP are listed as below. Submit your manuscript to us via either submit@scirp.org or Online Submission Portal.
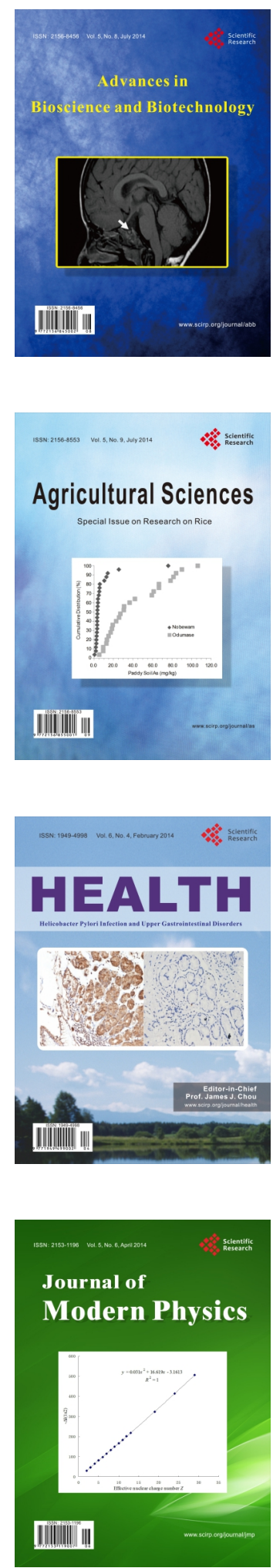
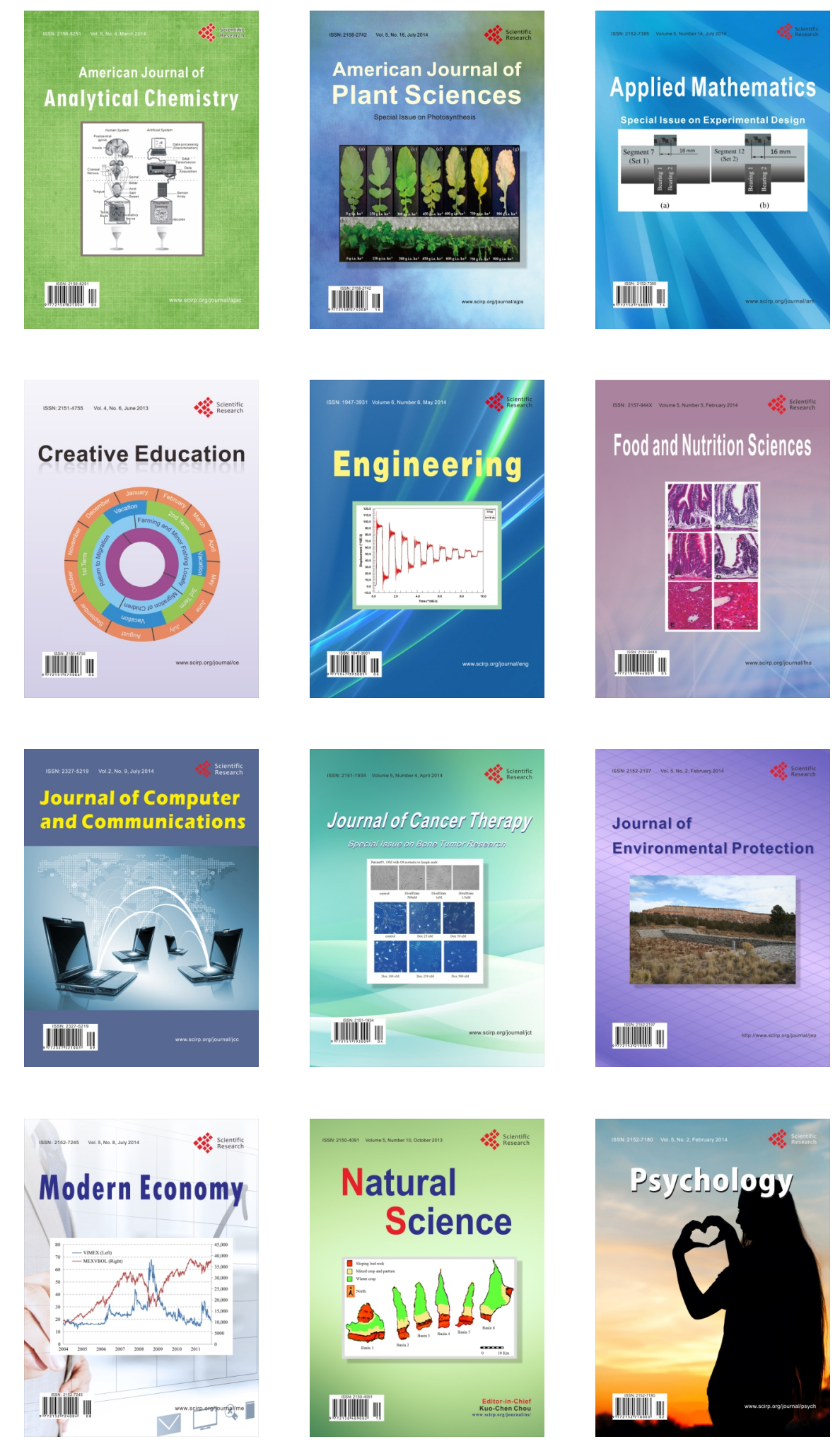